\title{
Feeding Children in a Rural Area: Proper Nutrition and Psycho-Social Development
}

\author{
Adriana Luz Martinez Piñeiro ${ }^{1}$, Simonetta Ballali ${ }^{2}$, Paola Berchialla ${ }^{3}$, Daniele Chiffi ${ }^{4}$, Maria del \\ Socorro del Rio Angulo ${ }^{5}$, Francesco Giunta ${ }^{6}$, Rossana Stanchi ${ }^{7}$ and Dario Gregori ${ }^{4, *}$ \\ ${ }^{1}$ Centro de Desarrollo Comunitario Maria de Guadalupe, Crecemos, Monte Albán, Mexico \\ ${ }^{2}$ ProchildOnlus, Trieste, Italy \\ ${ }^{3}$ Department of Public Health, University of Turin, Turin, Italy \\ ${ }^{4}$ Unit of Biostatistics, Public Health and Epidemiology, Dept. Cardiology, Thoracic and Vascular Sciences, University \\ of Padova \\ ${ }^{5}$ Crecemos, Mexico \\ ${ }^{6}$ Department of IV Anesthesia of Pisa, Pisa, Italy \\ ${ }^{7}$ Fondazione AVSI, Mexico
}

\begin{abstract}
Children nutrition in early life plays a relevant role not only in general health but also in development, with special regards to school performances and attention. Desarrollo Integral de la Juventud Oaxaqueña (DIJO) is a nongovernmental association which since 1993 has developed programs directed towards the education of children, youth and families in and around the city of Oaxaca. This study was performed from February 2009 to July 2011, and involved a total of 286 children from 1 st to 6th grade. The principal aim was to assess the results of the Educational intervention performed in the colonies of Monte Alban, Tlalixtac and Xoxocotlan, Oaxaca, Mexico. Two types of questionnaires were administered to children. The first one, shorter, consisted in 16 questions, divided into 4 areas of investigation: communication, comprehension, artistic expression and development. The second questionnaire was an expanded version of the previous one, administered in Monte Alban colony. When considered the data of the whole number of participants, the evaluation of total score of all the groups showed a significant improvement from the initial phase to the final one $(\mathrm{p}<0.001)$. After performing a multiple comparison of the three phases of the cycle (initial-final, intermediate-final, initialintermediate), the results indicated a significant improvement when considering all initial phases initial $(p<0.001)$. The results were all consistent in showing a significant improvement in all considered domains, proving therefore the successfulness of the method in addressing both facets of the problem.
\end{abstract}

Keywords: Children, desarollo, educational intervention, nutrition, Oaxaca, questionnaire.

\section{INTRODUCTION}

Children nutrition in early life plays a relevant role not only in general health but also in development, with special regards to school performances and attention. Mexico has implemented several public actions in order to overcome the national issue of under nutrition in children [1]. Results published from the ENSANUT 2006 [2], compared to those of 1988's survey [3], showed that the prevalence of underweight decreased by $68.5 \%(10.8 \%$ in $1988,3.4 \%$ in 2006). Considering the effective national effort to provide proper nutrients to children [4], several associations are assisting Mexican children both in fighting malnutrition and fostering social and cognitive development [5]. Desarrollo

*Address correspondence to this author at the Unit of Biostatistics, Public Health and Epidemiology, Dept. Cardiology, Thoracic and Vascular Sciences, University of Padova, University of Padova, Via Loredan, 18, 35121 Padova - Italy, Tel: +39 049 8275384; Fax: +39 02 700445089;

E-mail: dario.gregori@unipd.it
Integral de la Juventud Oaxaqueña (DIJO) is a nongovernmental association which is part of the AVSI (Associazione Volontari per ilServizio Internazionale) international network. Since 1993, DIJO has developed programs directed towards the education of children, youth and families in and around the city of Oaxaca. The main objective of the organization is to support the full development of children, youth and their families living in situations of poverty and marginalization. DIJO offers services in the fields of education, nutrition and health, and psychological counseling.

DIJO provides different services through the five existing educational centers in each of the neighborhoods where DIJO works. These interventions are performed in the fields of Health (referrals and follow-up of cases requiring emergency medical attention and specialized care, complementary food resources to the needy, preventive health measures and good hygiene practices), Education (academic support for children without access to school or in 
risk of dropping out, psycho-educational care, in particular for children with learning disabilities and behavioral problems, as well as for those children with socialization difficulties or victims of domestic violence, extra-curricular activities including recreation, culture and sports, computer courses for children and adolescents), Family (home visits to understand the socio-economic dynamics of the communities and to detect problems requiring immediate attention, like psychological care and therapy for parents on an as-needed basis) and Nutrition (providing breakfast (Comedor) daily to more than 150 children in the community kitchen called, "La Compañía", where balanced meals are prepared with the support of a volunteer nutritionist, training in the nutritional needs of children and in food preparation is offered to the mothers of beneficiaries, regularly assessing weight and height measures of the children).

In Monte Alban colony, a high degree of school defection was observed, increasing the number school's drop out children. In this background, particular attention was addressed on symptoms like tiredness, weakness and a lack of energy to perform basic daily activities.

This study aimed at assessing the results of the Educational intervention performed from February 2009 to July 2011 in the colonies of Monte Alban, Tlalixtac and Xoxocotlan, Oaxaca, Mexico.

\section{MATERIAL AND METHODS}

The study was performed from February 2009 to July 2011 , involving a total of 286 children from 1 st to 6 th grade. Two types of questionnaires were administered to children. The first one, shorter, consisted in 16 questions, divided into 4 areas of investigation: communication (written and oral), comprehension (logic and mathematics), artistic expression (production and understanding) and development (personal and social). This questionnaire was drafted in three variations in order to better suit to specific age groups' skills and knowledge: questionnaire A was meant for 1 st and 2 nd grade children, B for 3 rd and 4 th graders, $\mathrm{C}$ for 5 th and 6 th graders. The original questionnaire is presented in Table $\mathbf{1 .}$ The second questionnaire was an expanded version of the previous one, administered in Monte Alban colony (questionnaire D), aiming at deepening knowledge on the same areas previously investigated, and was given in the same format to all age groups.

Children were assessed in three phases: initial, intermediate and final. The evaluation scale was set at three levels: skill performed with difficulties (ACD), developing skill (AEP), skill developed (AL). In order to perform the statistical analysis, the ordinal scale was considered as an interval scale, with 1 corresponding to ACD, 2 corresponding to AEP and 3 corresponding to AL. An overall score was then calculated by a simple sum of the single items score for both questionnaires at each phase.

Significant differences were assessed with Friedman test with a series of post hoc Wilcoxon tests on each pair. Pvalue adjustment for multiple comparisons was performed.

The authors performed an in depth analysis of the first questionnaire, evaluating the scores of each of the four domains. In this case, separate evaluations of the 3 variations were performed. The data were analyzed with $\mathrm{R}$ version 2.15 [6].

\section{RESULTS}

Data of 286 children were considered. The evaluation of total score of all the groups showed a significant improvement from the initial phase to the final one $(p<0.001)$, as shown in Table 2 . Children from $1^{\text {st }}-2^{\text {nd }}$ grade undergoing the program showed a significant improvement within the cycle $(\mathrm{p}<0.001)$. After performing a multiple comparison of the three phases of the cycle (initial-final, intermediate-final, initial-intermediate), the results indicated a significant improvement when considering all initial phases $(p<0.001)$. Same considerations could be performed when considering $3^{\text {rd }}-4^{\text {th }}$ and $5^{\text {th }}-6^{\text {th }}$ grade children as presented in Fig. (1). In all three groups, time was significantly associated with skills development, as seen in Fig. (2). Age and time interaction was considered in order to assess a significant difference among the three groups. No association was found when considering different school grades. The four areas of development were subsequently analyzed, separated by school grades. Results are given in Table 3.

The second questionnaire was administered to a smaller group of children in Monte Alban. It presented general improvement $(\mathrm{p}<0.001)$, with significantly positive results already at the intermediate evaluation. Results are presented in Table 4.

\section{DISCUSSION}

Ensuring that all children complete primary schooling is among the primary objectives of the United Nations Millennium Development Goals [7]. Many children in developing countries are exposed to multiple risks such as poor development, including poverty, and poor health and nutrition. Grantham-McGregor [8] identified the prevalence of early childhood stunting and the number of people living in absolute poverty, as indicators of poor development. He showed that both indicators were closely associated with poor cognitive and educational performance in children and estimating a worldwide prevalence of over 200 million children under the age of 5 years that were not fulfilling their developmental potential. Disadvantaged children are destined not only to be less educated and have poorer cognitive function than their peers but also to be less productive [8].

Over the last two decades, Mexico has successfully improved national nutritional status, but many challenges still remain [9]. Despite the documented reductions [2, 3], the prevalence of stunting remains high, particularly among lower income and indigenous infants and children. Early malnutrition appears moreover to have late consequences, as considered from Huang [10], that analyzed the effect of early life conditions on functional health status in adulthood. His retrievals showed that childhood nutritional deprivation and poor health as well as low socio-economic status of the family of origin were significant predictors of adult dysfunctionalities. An interesting finding from a study conducted by Galler [11] was that early malnutrition (with its accompanying conditions during infancy) and not 
Table 1. Original Questionnaire Utilized for Children Evaluation

\section{Cuestionario A}

\section{Comunication Verbal y Escrita}

\begin{tabular}{|c|l}
\hline Q01 & Desarrollo de la percepción visual \\
\hline Q02 & Desarrollo de la percepción auditiva \\
\hline Q03 & Comprende y expresa la información oral y escrita \\
\hline Q04 & Logra comunicarse a través de escritos de manera convencional y no convencional. \\
\hline Comprensión Lógica-Matemàtica \\
\hline Q05 & Resuelve problemas aditivos que implican cálculo mental \\
\hline Q06 & Desarrolla la habilidad para trazar grecas y mosaicos con figuras geométricas \\
\hline Q07 & Desarrollo de la habilidad mental a partir de juegos \\
\hline Q08 & Clasificar y ordenar, agrupar, desagrupar, figuras u objetos (Tamaño, colores, formas,etc) \\
\hline
\end{tabular}

Expresión y Apreciación Artística

\begin{tabular}{l|l} 
Q09 & Desarrollo de la habilidad motriz, fina y gruesa \\
\hline Q10 & Coordinación de movimientos corporales con ritmos a partir de cantos y rimas \\
\hline Q11 & Utiliza su imaginación y creatividad para desarrollar las artes plásticas \\
\hline Q12 & Logra controlar su cuerpo y su mente al escuchar música \\
\hline
\end{tabular}

Desarrollo Personal y Social

\begin{tabular}{|l|l} 
Q13 & Reconoce y respeta las normas establecidas en el centro educativo \\
\hline Q14 & Muestra respeto al interactuar con otras personas \\
\hline Q15 & Cuida su higiene personal y de los espacios que utiliza \\
\hline Q16 & Asiste diariamente y puntual al curso \\
\hline
\end{tabular}

\section{Cuestionario B}

Comunicación Verbal y Escrita

\begin{tabular}{|c|l|}
\hline Q01 & Idenfica por su estructura diversos tipos de textos \\
\hline Q02 & Comprende y expresa de forma oral y/o escrita diversas situaciones \\
\hline Q03 & Reconoce y aplica reglas ortográficas básicas \\
\hline Q04 & Comprende diversos tipos de textos \\
\hline Comprensión lógica-matemática \\
\hline Q05 & Comprende y utiliza las unidades de medida \\
\hline Q06 & Domina las operaciones matemáticas básicas y las utiliza en situaciones cotidianas \\
\hline Q07 & Expresa las cantidades hasta decena de millar \\
\hline Q08 & Comprende y utiliza las fracciones en situaciones cotidianas \\
\hline Expresión y Apreciación Artística \\
\hline Q09 & Utiliza su imaginación y creatividad para expresar ideas y sentimientos \\
\hline Q10 & Realiza movimientos corporales para expresar habilidades artísticas \\
\hline Q11 & Representación de ideas y sentimientos a través del modelado de figuras en distintos materiales \\
\hline
\end{tabular}


Table 1. contd..

\begin{tabular}{|c|c|}
\hline Q12 & Manifiesta sus emociones a través de la música y las artes plásticas \\
\hline \multicolumn{2}{|c|}{ Desarrollo Personal y Social } \\
\hline Q13 & Reconoce y respeta las normas establecidas en el centro educativo \\
\hline Q14 & Convive sanamente prácticando los valores sociales \\
\hline Q15 & Muestra cuidado en su higiene personal y aspecto físico \\
\hline Q16 & Cumple con responsabilidad en acciones cotidianas \\
\hline \multicolumn{2}{|r|}{ Cuestionario $\mathrm{C}$} \\
\hline \multicolumn{2}{|c|}{ Comunicación Verbal y Escrita } \\
\hline Q01 & Se comunica de manera oral y escrita con claridad y coherencia \\
\hline Q02 & Identifica, utiliza, escribe, analiza y comprende diversos tipos de textos \\
\hline Q03 & Lee en voz alta con ritmo, claridad y entonación respetando signos ortográficos \\
\hline Q04 & Revisa sus escritos y corrige las dificultades ortográficas y de narración \\
\hline \multicolumn{2}{|c|}{ Comprensión Lógica-Matemática } \\
\hline Q05 & Explica y utiliza eficientemente las reglas del sistema decimal \\
\hline Q05 & Resuelve problemas usando las operaciones elementales en unidades de medida \\
\hline Q06 & Obtiene, organiza, analiza y representa información numérica \\
\hline Q07 & Clasifica, relaciona, construye figuras y cuerpos geométricos \\
\hline \multicolumn{2}{|c|}{ Expresión y Apreciación Artística } \\
\hline Q08 & Utiliza diversas formas artísticas para expresar ideas, pensamientos y emociones. \\
\hline Q09 & Utiliza diversos materiales crear formas y figuras artísticas \\
\hline Q10 & Coordina sus movimientos con cantos, ritmos y melodías \\
\hline Q11 & Interpreta personajes utilizando imaginación y creatividad \\
\hline \multicolumn{2}{|c|}{ Desarrollo Personal y Social } \\
\hline Q12 & Reconoce y respeta las normas establecidas en el centro educativo \\
\hline Q13 & Reconoce y practica los valores con sus compañeros \\
\hline Q14 & Muestra buenos hábitos de higiene \\
\hline Q15 & Participa activamente en todas las actividades \\
\hline
\end{tabular}

Table 2. Evaluation of Total Scores Measured within a Full Cycle. The Number of Evaluated Children is Shown in Brackets

\begin{tabular}{|c|c|c|c|c|}
\hline & Initial & Intermediate & Final & Trend Test \\
\hline \hline \multirow{2}{*}{ Cuestionario A } & $(\mathrm{N}=125)$ & $(\mathrm{N}=125)$ & $(\mathrm{N}=125)$ & $\mathrm{p}<0.001$ \\
\cline { 2 - 5 } & $1.19 / 1.38 / 1.95$ & $1.73 / 2.09 / 2.28$ & $2.27 / 2.88 / 3.000$ & $(\mathrm{~N}=102)$ \\
\hline \multirow{2}{*}{ Cuestionario B } & $(\mathrm{N}=101)$ & $(\mathrm{N}=101)$ & $2.34 / 2.75 / 2.97$ & $\mathrm{p}<0.001$ \\
\cline { 2 - 5 } & $1.27 / 1.50 / 1.69$ & $1.75 / 2.00 / 2.25$ & $(\mathrm{~N}=59)$ & $\mathrm{p}<0.001$ \\
\hline \multirow{2}{*}{ Cuestionario C } & $(\mathrm{N}=59)$ & $(\mathrm{N}=59)$ & $2.31 / 2.75 / 3.00$ & \\
\hline
\end{tabular}



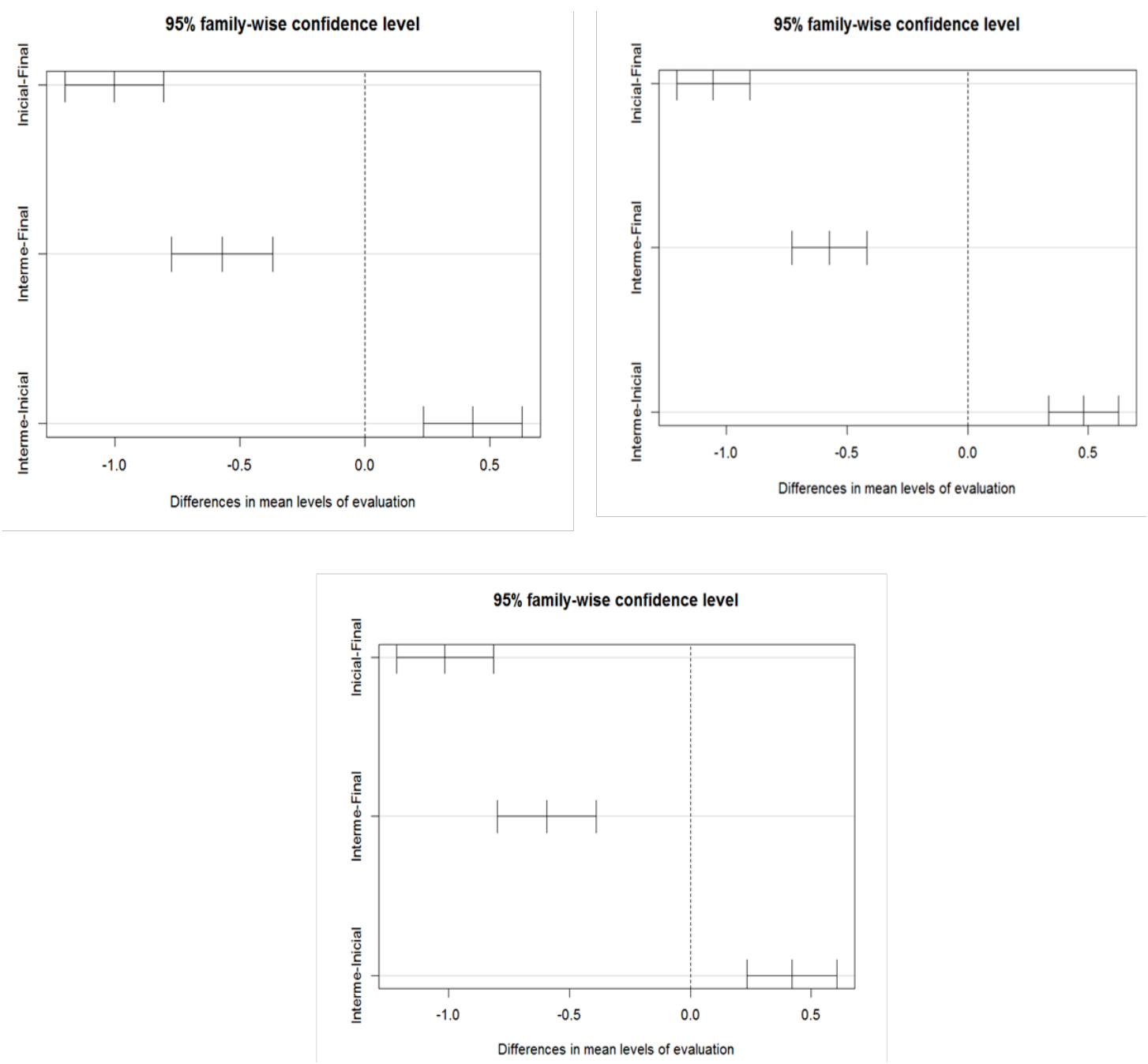

Fig. (1). Multiple comparison between program phases. The graphics picture (clockwise starting from the left) the evaluations of questionnaires $\mathrm{A}, \mathrm{B}$ and $\mathrm{C}$.

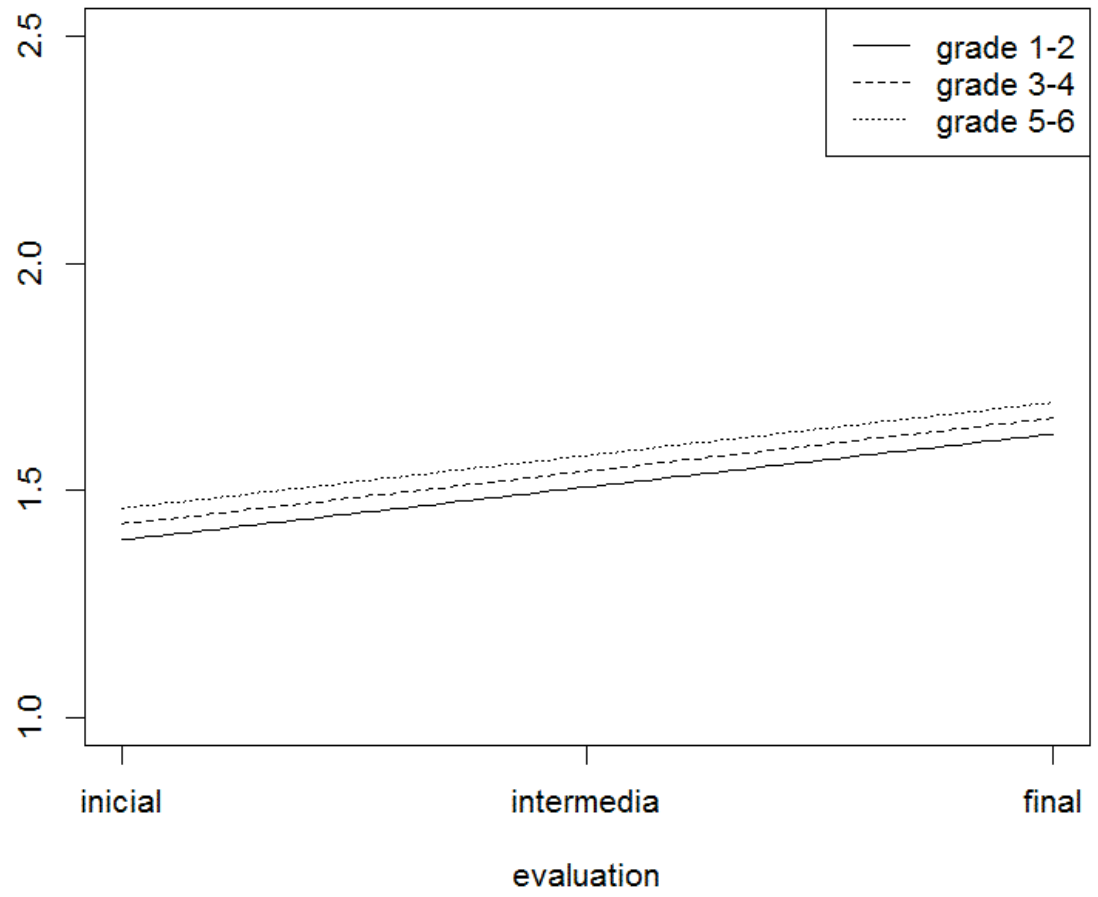

Fig. (2). Age and time interaction. Questionnaire A, B and C were considered as a whole. 
Table 3. Questionnaires Domains and Calculated Scores. The Number of Evaluated Children is Shown in Brackets

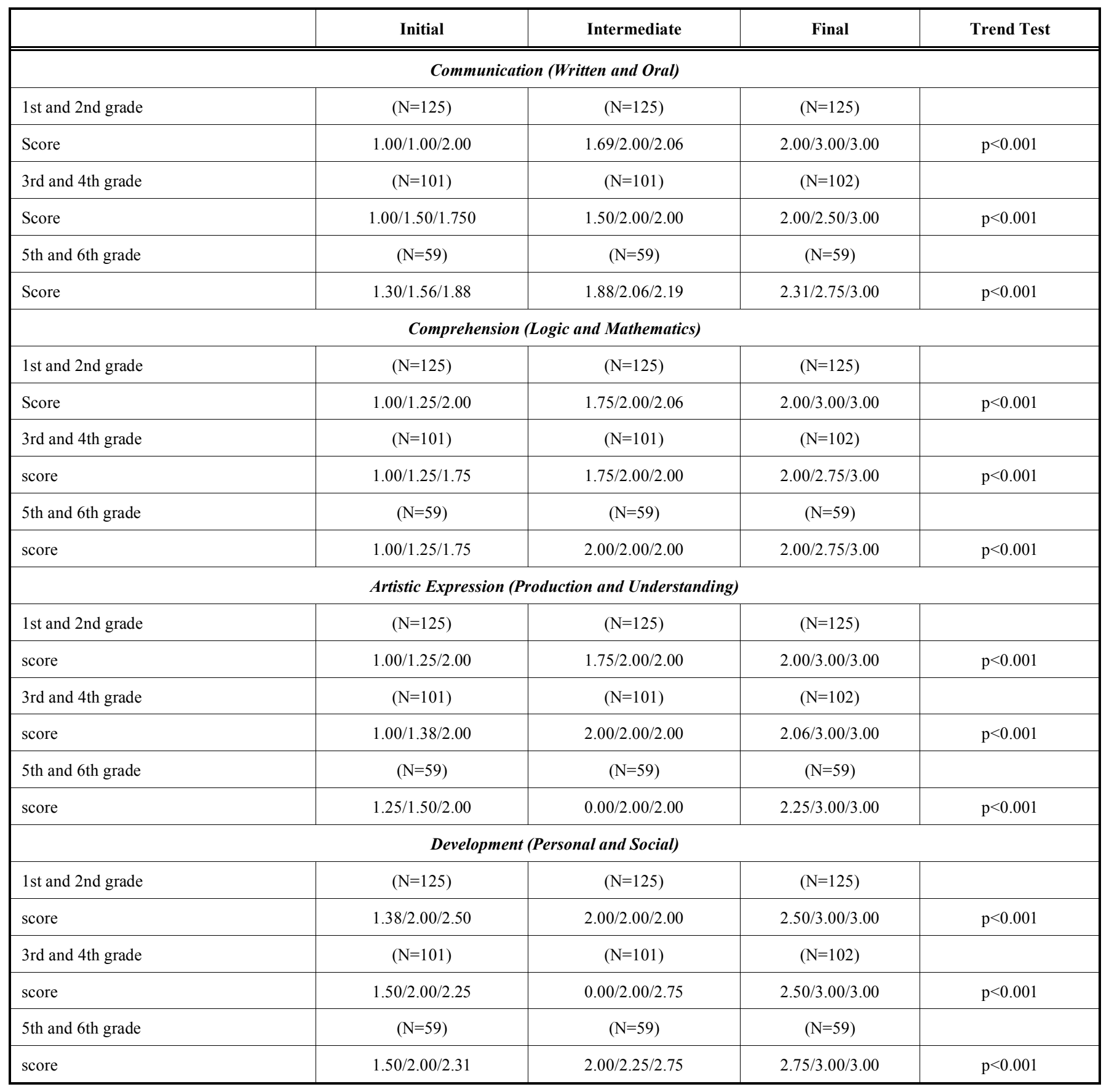

Table 4. Evaluation of the Total Score of the Questionnaire D

\begin{tabular}{|c|c|c|c|c|}
\hline & Initial & Intermediate & Final & Trend Test \\
\hline \hline \multirow{2}{*}{ Questionnaire D } & $(\mathrm{N}=32)$ & $(\mathrm{N}=32)$ & $(\mathrm{N}=32)$ & \\
\cline { 2 - 5 } & $1.31 / 1.67 / 1.92$ & $1.75 / 1.89 / 2.03$ & $2.53 / 2.67 / 2.76$ & $\mathrm{P}=0.002$ \\
\hline
\end{tabular}

socioeconomic conditions at the time of the study, was the major contributor to poor academic performance in schoolaged children. DIJO's program is set in extremely poor environments, with the specific aim to promote children development within difficult socio-economic and social conditions. As similarly seen in India's poor environments, where the attempts are being made to help schoolchildren learning about nutrition issues and facilitating transfer of knowledge to the children through a set of model lessons [12]. 
A number of micronutrients are therefore required for optimal physical growth and neuromotor development. Isolated deficiencies of micronutrients are considered as rare in clinical practice and instead, habitually deficiencies of multiple micronutrients co-exist [13]. The influence of early malnutrition affects not only physical well-being but also behavioral and intellectual developments [14]. In 2010, Benton [15] considered the influence of dietary status on the cognitive performance of children, presenting an overview of the present knowledge on brain development and its linkage to malnutrition. Gross malnutrition resulted in problems affecting both short- and long- term cognitive and behavioral problems, especially when considering developing countries, where evidences were supporting adequate diet's significant and lasting implications for cognitive functioning. Moreover, early malnutrition has an almost irreversible effect on growth, both physical and mental. As considered in that research [15] certain dietary deficiencies during the first 2 years of life, for example iodine and iron, create problems that are not reversed by a later adequate diet. Communitybased food and nutrition programs have been broadened with the aim of promoting children development also at other levels, focusing on academic performances and social skills [16]. Breakfast load is considered as fundamental to enhance and foster academic development, taken its influence on attention [17].

DIJO's work sets itself in this framework, ensuring proper meals to children and providing an educational intervention for elementary school children, followed in a yearly cycle during school time. DIJO daily provided a balanced breakfast for children, divided in three groups according to their nutritional status (normal BMI, slightly underweight, markedly underweight). Starting from a basic daily breakfast of 400 Kcalories (Kcal), meals were composed by $60 \%$ carbohydrates, $15 \%$ proteins and $25 \%$ lipids, with a fair distribution of mono- and polyunsaturates fats, vitamins, minerals and dietary fiber. Each child received a meal with an energetic intake equal to the $35 \%$ of the daily ratio, as recommended from the Instituto Nacional de Ciencias Médicas y Nutrición Salvador Zubirán (INNSZ): small portions $/ 450 \mathrm{Kcal}$ (for children from 1 to 5), medium portions/630Kcal (for children from 6 to 11 ) and big portions $/ 900 \mathrm{Kcal}$ (for children from 12 till 18 years).

As considered by Grantham-McGregor et al., who reviewed a series of studies assessing the relationship between mental development and severe malnutrition [18], it is reasonable to attribute a causal relationship to early childhood malnutrition and poor performance on cognitive tests in later childhood. In their review, the authors stated in addition that there was a certain possibility that previously malnourished children who received little nutritional supplementation coped less well with frustrating or competitive situations. Same considerations were established by Strupp in 1995's theoretical reappraisal of the literature on the enduring effects of early malnutrition [19].

In the present study, all analyses showed a substantial improvement in all the considered domains (communication, logic, artistic skill and social and personal development) from the first phases of the intervention, and already between the initial and the intermediate evaluation a positive development of all domains was recorded. These progresses appeared to be significantly enhanced when children attained the course for a full period (from the initial phase to the final phase), especially for the younger kids belonging to $1^{\text {st }}$ and $2^{\text {nd }}$ grades. As hypothesized, children appeared to profit the most from the academic support offered from DIJO assistants, presenting a significant improvement in logic and mathematics comprehension.

An important element in DIJO's program is the coexistence of a double sided vision of children's sustainment. On the one hand, a balanced breakfast is daily provided, while on the other, academic and social help is offered from the first years of school. This methods is in line with previous consistent considerations, stating that malnourished children show a deficit in tests of cognitive function or intelligence if they return to poor environments [18]. In Eilander systematic review of trials held to understand the influence of a multiple micronutrient supplementation on academic performance, results showed a marginal increase in performance [20]. Similarly, Benton considered in several studies the influence of micronutrients on schoolchildren and their performances [21-23], with a significant increase in non-verbal intelligence in the groups receiving supplementation. DIJO's intervention positively influenced this domain as well, with both artistic and logic skills boosted throughout the period. Wang, more recently, performed a study on 220 students from 8-12 years, reaching the same considerations [24]. Verbal learning and memory, as found here, were enhanced also in NEMO (Nutrition Enhancement for Mental Opti- mization) study group's trials [25].

The present program aimed moreover to improve social skills in children, as the capacity of well behave among groups and the achievement of prolific relationship among children, in order to increase school performances.

A fundamental achievement of DIJO's program has certainly been the capacity to deliver sustainment for a long period of time, strongly committing to boost children regular attendance. As seen from Ramakrishnan [26], the benefits of providing nutrients supplements during critical periods of growth and development can be seen only when supplements are consumed regularly.

Overall, the literature suggests that good regular dietary habits are the best way to ensure optimal mental and behavioral performance at all times. As considered by Bellisle [27], it is fundamental to consider that beside nutritional factors affecting cognition and behavior development, numerous individual (e.g. psychological, emotional), familial and social factors can affect scholastic achievement and successful integration. DIJO's intervention was therefore analyzed in order to establish the efficacy of the intervention on elementary children who adverted to their centers in 3 different colonies in Oaxaca. Results were all consistent in showing a significant improvement in all considered domains, proving therefore the successfulness of method in addressing both facets of the problem.

\section{CONFLICT OF INTEREST}

The authors confirm that this article content has no conflicts of interest. 


\section{ACKNOWLEDGEMENTS}

This research was partially funded by an unrestricted grant of the University of Padova and of Prochild ONLUS. The work has been partially supported by an unrestricted grant of the Italian Ministry of Foreign Affairs under the program "Programmi di alta rilevanza scientifica e tecnologica Italia-Messico".

\section{REFERENCES}

[1] Rivera JA, Sepulveda Amor J. Conclusions from the Mexican National Nutrition Survey 1999: translating results into nutrition policy. Salud Publica Mex 2003; 45 (Suppl 4): S565-75.

[2] Olaiz G, Rivera J, Shamah T, et al. Encuesta Nacional de Salud y Nutrición 2006. Cuernavaca: Instituto Nacional de Salud Pública 2006.

[3] epulveda-Amor J, Angel Lezana M, Tapia-Conyer $\mathrm{R}$, et al. [Nutritional status of pre-school children and women in Mexico: results of a probabilistic national survey]. Gac Med Mex 1990; 126 (3): 207-24; discussion 24-6.

[4] Mesoamerica Nutrition Program Targeting Study G. Targeting performance of three large-scale, nutrition-oriented social programs in Central America and Mexico. Food Nutr Bull 2002; 23(2): 16274.

[5] Bradshaw YW, Schafer MJ. Urbanization and development: The emergence of international nongovernmental organizations amid declining states. Sociol Perspect 2000; 43 (1): 97-116.

[6] R. A Language and Environment for Statistical Computing. Vienna, Austria: R Foundation for Statistical Computing 2008.

[7] UN. Road map toward the implementation of the United Nations Millennium Declaration. New York: United Nations 2002.

[8] Grantham-McGregor S, Cheung YB, Cueto S, et al. Developmental potential in the first 5 years for children in developing countries. Lancet 2007; 369 (9555): 60-70.

[9] Rivera JA, Irizarry LM, Gonzalez-de Cossio T. Overview of the nutritional status of the Mexican population in the last two decades. Salud Publica Mex 2009; 51 (Suppl) 4:S645-56.

[10] Huang C, Soldo BJ, Elo IT. Do early-life conditions predict functional health status in adulthood? The case of Mexico. Soc Sci Med 2011; 72(1): 100-7.

[11] Galler JR, Ramsey F, Solimano G. The influence of early malnutrition on subsequent behavioral development III. Learning disabilities as a sequel to malnutrition. Pediatr Res 1984; 18(4): 309-13.

[12] Bamji MS, Murthy PV. Promotion of the feeding minds and fighting hunger initiative in selected rural schools in Andhra Pradesh, India. Food Nutr Bull 2006; 27 (2): 105-13.
[13] Singh M. Role of micronutrients for physical growth and mental development. Indian J Pediatr 2004; 71(1): 59-62.

[14] Meeks Gardner J, Grantham-McGregor SM, Chang SM, et al. Activity and behavioral development in stunted and nonstunted children and response to nutritional supplementation. Child Dev 1995; 66(6): 1785-97.

[15] Benton D. The influence of dietary status on the cognitive performance of children. Mol Nutr Food Res 2010; 54(4): 457-70.

[16] Mahoney CR, Taylor HA, Kanarek RB, et al. Effect of breakfast composition on cognitive processes in elementary school children. Physiol Behav 2005 7; 85(5): 635-45.

[17] Benton D, Maconie A, Williams C. The influence of the glycaemic load of breakfast on the behaviour of children in school. Physiol Behav 2007 23; 92(4): 717-24.

[18] Grantham-McGregor S. A review of studies of the effect of severe malnutrition on mental development. J Nutr 1995; 125(8 Suppl): 2233S-8S.

[19] Strupp BJ, Levitsky DA. Enduring cognitive effects of early malnutrition: a theoretical reappraisal. J Nutr 1995; 125 (8 Suppl): 2221S-32S.

[20] Eilander A, Gera T, Sachdev HS, et al. Multiple micronutrient supplementation for improving cognitive performance in children: systematic review of randomized controlled trials. Am J Clin Nutr 2010;91(1):115-30.

[21] Benton D, Roberts G. Effect of vitamin and mineral supplementation on intelligence of a sample of schoolchildren. Lancet 1988 23; 1(8578): 140-3.

[22] Benton D, Buts JP. Vitamin/mineral supplementation and intelligence. Lancet 1990 12; 335(8698): 1158-60.

[23] Benton D, Cook R. Vitamin and mineral supplements improve the intelligence scores and concentration of 6 -year-old children. Pers Individ Dif 1991 (12): 1151-8.

[24] Wang Y, Yin S, Zhao X, et al. [Study on the effect of micronutrients supplementation on health status of children]. Wei Sheng Yan Jiu 2003; 32(5): 455-8

[25] Osendarp SJ, Baghurst KI, Bryan J, et al. Effect of a 12-mo micronutrient intervention on learning and memory in wellnourished and marginally nourished school-aged children: 2 parallel, randomized, placebo-controlled studies in Australia and Indonesia. Am J Clin Nutr 2007; 86(4): 1082-93.

[26] Ramakrishnan U, Neufeld LM, Flores R, et al. Multiple micronutrient supplementation during early childhood increases child size at 2 y of age only among high compliers. Am J Clin Nutr 2009; 89(4):1125-31.

[27] Bellisle F. Effects of diet on behaviour and cognition in children. Br J Nutr 2004; 92 (Suppl 2): S227-32.

(C) Piñeiro et al.; Licensee Bentham Open.

This is an open access article licensed under the terms of the Creative Commons Attribution Non-Commercial License (http://creativecommons.org/licenses/by-nc/3.0/) which permits unrestricted, non-commercial use, distribution and reproduction in any medium, provided the work is properly cited. 